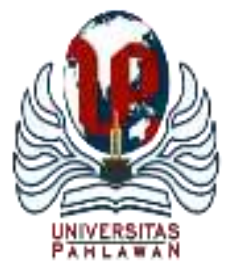

Edukatif : Jurnal Ilmu Pendidikan Volume 4 Nomor 1 Tahun 2022 Halm 107 - 115

EDUKATIF: JURNAL ILMU PENDIDIKAN

Research \& Learning in Education

https://edukatif.org/index.php/edukatif/index

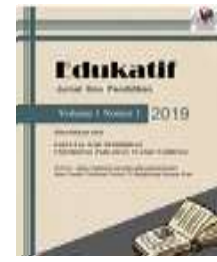

\title{
Peran Pemuda Lintas Agama dalam Meningkatkan Kerukunan Umat Beragama di Provinsi Kalimantan Timur
}

\author{
Deandlles Christover ${ }^{\bowtie}$ \\ Universitas Widya Gama Mahakam Samarinda, Indonesia \\ E-mail : endenz_grafft@yahoo.com
}

\begin{abstract}
Abstrak
Tujuan penelitian ini adalah untuk mengetahui bagaimana peran yang dilakukan oleh Pemuda Lintas Agama dalam meningkatkan kerukunan umat beragama di Provinsi Kalimantan Timur sehingga mewujudkan sebuah tatanan kehidupan masyarakat majemuk yang harmonis. Penelitian ini bersifat deskriptif kualitatif. Adapun analisis data yang digunakan adalah analisis data model interaktif yang dikemukakan oleh Miles, Huberman, dan Saldana, dimana analisis data ini terdiri dari pengumpulan data, kondensasi data, penyajian data dan penarikan kesimpulan. Penelitian ini menggunakan teknik pengumpulan data sekunder dengan melakukan penelitian kepustakaan dan sumber-sumber data sekunder lainnya serta melakukan penelitian langsung ke lapangan untuk mendapatkan data primer melalui wawancara yang mendalam. Dari hasil penelitian yang dilakukan, menunjukan bahwa Peran Pemuda Lintas Agama Dalam Meningkatkan Kerukunan Umat Beragama di Provinsi Kalimantan Timur menunjukan bahwa sejauh ini peran Pemuda Lintas Agama berjalan dengan baik, hal tersebut dikarenakan FKUB dan Pemuda Lintas Agama dinilai mampu menyangga kondusifitas dua elemen penting di masyarakat, yaitu orang tua dan para pemuda. Hal tersebut diperkuat dengan fakta kondisi keberagamaan di Kalimantan Timur yang relatif aman dan tentram.
\end{abstract}

Kata Kunci: Peran, Lintas Agama, Pemuda, Kerukunan

\section{Abstract}

The purpose of this research is to find out how the role of the Interfaith Youth in increasing the harmony of religious people in East Kalimantan Province to create a harmonious pluralistic society. This research is descriptive qualitative. The data analysis used is an interactive model data analysis presented by Miles, Huberman, and Saldana, where data analysis consists of data collection, data condensation, data presentation, and drawing conclusion. This study uses secondary data collection techniques by conducting library research and other secondary data sources as well as conducting research directly into the field to obtain primary data through in-depth interviews. From the results of research conducted, it shows that the Role of Youth Interfaith in Increasing Harmony in Religious Communities in East Kalimantan Province shows that so far the role of Interfaith Youth has been going well, this is because FKUB and Interfaith Youth are considered capable of supporting the conduciveness of two important elements in society, namely parents and young people. This is reinforced by the fact that religious conditions in East Kalimantan are relatively safe and peaceful.

Keywords: Role, Interfaith, Youth, Harmonious.

Copyright (c) 2022 Deandlles Christover

$\triangle$ Corresponding author:

Email : endenz_grafft@yahoo.com

DOI : https://doi.org/10.31004/edukatif.v4i1.1762

ISSN 2656-8063 (Media Cetak)

ISSN 2656-8071 (Media Online)

Edukatif : Jurnal Ilmu Pendidikan Vol 4 No 1 Tahun 2022

p-ISSN 2656-8063 e-ISSN 2656-8071 


\section{PENDAHULUAN}

Sebagai negara kesatuan yang terdiri dari berbagai macam kemajemukan etnis, budaya, serta agama yang merupakan identitas yang melekat pada masyarakatnya, maka keanekaragaman tersebut harus dipahami sebagai suatu kenyataan yang harus disyukuri sebagai kekayaan bangsa. Hal ini disebabkan karena kondisi letak geografis Indonesia yang terdiri dari berbagai pulau yang memiliki perbedaan-perbedaan sosial budaya, sehingga mengakibatkan munculnya berbagai macam ikatan-ikatan primordial maupun identitas-identitas yang menyangkut pada ciri khas bangsa Indonesia itu sendiri, akan tetapi perbedaan-perbedaan identitas ini maupun ikatan primordial yang ada dapat dipersatukan dalam Kebhinekaan Tunggal Ika pada bingkai Negara Kesatuan Republik Indonesia (Simamora, 2019). Di sisi lain, perbedaan-perbedaan yang ada khususnya perbedaan pada ikatan primordial bangsa Indonesia disebabkan Indonesia itu sendiri memiliki berbagai macam model dan pola kehidupan adat-istiadat serta budaya sehingga tidak jarang mengakibatkan kerawanan sosial yang berpotensi konflik sipil dalam kehidupan beragama. Salah satu provinsi yang memiliki tingkat kemajukan tinggi adalah Provinsi Kalimantan Timur.

Seperti provinsi lainnya, Kalimantan Timur juga dihuni oleh penduduk yang terdiri dari berbagai macam suku, bangsa, etnis, ikatan primordial, serta agama sebagai identitas yang melekat pada masingmasing penduduk. Dilihat dari suku-suku yang ada dan mendiami Provinsi Kalimantan Timur, maka suku pribumi terbagi menjadi dua kelompok suku menurut lingkungan hukum adatnya yaitu Kelompok Hukum Adat Melayu yang terdiri dari Suku Banjar yang mayoritas berdomisili di Kota Balikpapan dan Samarinda. Sedangkan Suku Kutai lebih banyak berdomisili di Kabupaten Kutai Kartanegara, Kabupaten Kutai Timur, dan Kabupaten Kutai Barat. Sedangkan Kelompok Hukum Adat Dayak mayoritas Suku Paser berdomisili di Kabupaten Paser, dan Penajam Paser Utara, dan selanjutnya Suku Tunjung, Suku Benuaq, Suku Bentian, Suku Bentian, Suku Bukat, Suku Busang, Suku Ohong, Suku Penihing, Suku Punan, mayoritas berdomisili di Kabupaten Kutai Barat. Sedangkan Suku Modang lebih banyak berdomisili di Kutai Timur. Selanjutnya untuk Suku Ahe, Punan Sului, Punan Beketan, Punan Murut, Suku Badeng, Suku Bakung Metulang, Suku Merab, Suku Wehea lebih banyak bermukim di Kecamatan Muara Wahau, Kutai Timur. Kemudian untuk Suku Rumpun Apo Kenyah, lebih banyak berada di Kutai Barat dan Mahakam Ulu. Selain dihuni oleh berbagai macam suku, kemajemukan Provinsi Kalimantan Timur juga dapat dilihat dari beragamnya agama yang dipeluk oleh penduduk Kalimantan Timur dimana berdasarkan data BPS pada tahun 2015 agama yang mayoritas adalah Islam (85,57\%), Kristen $(9,41 \%)$, Katolik $(4,17 \%)$, Budha $(0,94 \%)$, Hindu $(0,28 \%)$, Kong $\mathrm{Hu} \mathrm{Cu}(0,05 \%)$ dan Kaharingan $(0,03 \%)$.

Melihat dari potensi rentannya terjadi perbedaan-perbedaan paham yang dapat mengakibatkan timbulnya rasa curiga antar kalangan umat beragama yang tentunya apabila hal seperti demikian tidak diatasi secara tepat, cepat atau lambat, suka atau tidak suka akan menyebabkan perpecahan di kalangan umat beragama yang ada di Kalimantan Timur. Hal ini terjadi karena sikap fanatisme diantara umat beragama yang masih menyatukan antara wilayah esoteris dan eksoteris dalam transeden keagamaan, sehingga masyarakat tidak akan pernah mencapai titik temu. Mengingat sangat sensitifnya isu-isu mengenai konflik keagamaan juga melahirkan pertanyaan bagi penulis mengenai bagaimana pola pembinaan yang seharusnya dilakukan kepada masyarakat dalam meningkatkan kerukunan umat beragama agar dapat berjalan secara harmonis dan toleran (Huda Thoriq, 2018).

Menariknya, Provinsi Kalimantan Timur telah dinobatkan menjadi bagian daerah provinsi paling rukun setelah Provinsi Kalimantan Utara dan Sulawesi Barat. Hal itu berdasarkan Keputusan Menteri Agama No. 1 Tahun 2019 yang dibacakan saat Upacara Peringatan Hari Amal Bakti Kementerian Agama RI, pada hari Kamis, 3 Januari 2019 di Jakarta. Prestasi daerah paling rukun tersebut diberi penghargaan Harmoni Award oleh Menteri Agama RI. Kalimantan Timur masuk dalam kategori daerah paling rukun berdasarkan indikator 
dari Badan Litbang dan Diklat Kementerian Agama, melihat kondisi faktual daerah terkait kasus intoleransi dan pemberitaan kerukunan.

Salah satu unit yang memiliki tugas dan fungsi untuk menciptakan kondisi kerukunan umat beragama tentu saja tidak lepas dari peran Pemuda Lintas Agama yang berada dibawah naungan Forum Kerukunan Umat Beragama. Pemuda Lintas Agama merupakan bentuk dari gabungan organisasi-organisasi keagamaan yang dipelopori oleh generasi muda. Kita sejatinya perlu senantiasa memperhatikan perkembangan dan gerak dinamis yang dilakukan oleh Pemuda Lintas Agama. Dalam hal ini, kepengurusan, keanggotaan, program, dan kegiatan yang ditampilkan oleh Pemuda Lintas Agama merupakan inti dari wajah asli setiap FKUB, yakni apakah Pemuda Lintas Agama sudah berjalan sesuai dengan harapan yang semestinya (Ahmad, 2010).

Tulisan ini mencoba untuk mengulas lebih jauh mengenai bagaimana peran pemuda dalam meningkatkan kerukunan umat beragama di Provinsi Kalimantan Timur, hal apa yang sudah dilakukan, dan keterkaitannya dengan ketahanan sosial masyarakat Kalimantan Timur dari ancaman konflik agama.

\section{METODE PENELITIAN}

Penelitian ini menggunakan metode kualitatif. Hal ini, sebuah pendekatan atau pencarian untuk menyelidiki dan memahami fenomena sentral (Raco, 2018). Penelitian kualitatif (qualitative research) adalah suatu penelitian yang ditujukan untuk mendiskripsikan dan menganalisis fenomena, peristiwa, aktivitas sosial, sikap, kepercayaan persepsi, pemikiran orang secara individual maupun kelompok. Penelitian kualitatif bersifat induktif maksudnya peneliti membiarkan permasalahan-permasalahan muncul dari data atau dibiarkan terbuka untuk interpretasi (Dr. Tjipto Subadi, 2006). Data dihimpun dengan pengamatan yang seksama, mencakup deskripsi dalam konteks yang mendetail disertai catatan-catatan hasil wawancara yang mendalam, serta hasil analisis dokumen dan catatan-catatan (Khadijah, 2018).

Penelitian ini merupakan penelitian deskriptif dengan menggunakan pendekatan kualitatif bertujuan untuk menjelaskan tentang peran Pemuda Lintas Agama dalam Meningkatkan Kerukunan Umat Beragama di Kalimantan Timur. Data dikumpulkan melalui wawancara, observasi dan studi literatur. Lokasi penelitian utama di kantor Kementerian Agama Wilayah Kalimantan Timur. Observasi juga dilakukan di lokasi terpilih, seperti tempat dimana diadakan kegiatan oleh Pemuda Lintas Agama. Dokumen-dokumen berupa Peraturan Pemerintah Daerah atau dokumentasi juga mendukung hasil penelitian ini. Data yang diperoleh di analisis dengan menggunakan metode analisis interaktif (Pangalila, 2018).

Dalam penelitian ini menggunakan teknik analisis data berupa analisis isi (content analysis). Analisis isi merupakan analis ilmiah tentang isi pesan suatu data. Analisis adalah serangkaian upaya sederhana tentang bagaimana data penelitian pada gilirannya dikembangkan dan diolah ke dalam kerangka kerja sederhana. Data yang sudah terkumpul kemudian dianalisis untuk mendapatkan informasi, namun terlebih dahulu data tersebut diseleksi atas dasar reliabilitasnya Tujuan dari analisis data ini adalah untuk mencari kebenaran dari data-data yang telah diperoleh, sehingga dari sini bisa ditarik kesimpulan dari hasil penelitian yang telah dilakukan. Dalam penelitian ini, peneliti menggunakan 3 tahapan, yaitu: reduksi data, display data, verifikasi data dan mengambil kesimpulan.

\section{HASIL DAN PEMBAHASAN PENELITIAN}

\section{Peran Pemuda Lintas Agama: Membantu Pelaksanaan Tugas dan Fungsi FKUB Prov. Kalimantan Timur}

Pemuda Lintas Agama sebagai organisasi kepemudaan dalam menjalankan tugasnya sejatinya tidak lepas dari membantu FKUB. Artinya bahwa FKUB dalam menjalankan tugas dan fungsinya turut serta dibantu oleh Pemuda Lintas Agama (Pradnyaningrat et al., 2020). Setiap ada acara-acara yang diselenggarakan oleh FKUB Provinsi Kalimantan Timur, maka dalam pelaksanaannya Pemuda Lintas Agama turut membantu FKUB dalam mempersiapkan segala hal yang dibutuhkan. Hal ini dapat dilihat dari berbagai 
110 Peran Pemuda Lintas Agama dalam Meningkatkan Kerukunan Umat Beragama di Provinsi Kalimantan Timur-Deandlles Christover

DOI: https://doi.org/10.31004/edukatif.v4i1.1762

macam kegiatan yang dilakukan oleh Pemuda Lintas Agama dalam mengikuti berbagai macam kegiatan yang dimaksud, khususnya kegiatan-kegiatan yang dilakukan oleh FKUB. Organisasi kepemudaan Pemuda Lintas Agama telah melaksanakan peran dan fungsinya secara optimal, khususnya dalam mensosialisasikan tentang kerukunan umat beragama sesuai dengan konsensus dasar mengenai empat pilar kebangsaan yang dilakukan melalui kegtiatan diskusi, dialog, jalan santai kerukunan, yang menurut hemat penulis ini adalah suatu kegiatan yang sangat efektif. Hal ini dikarenakan melalui kegiatan-kegiatan tersebut terjadi hubungan silahturahmi antar sesama umat beragama.

\section{Melakukan dialog Dengan Para Pemuda Lintas Agama dan Masyarakat}

Organisasi Pemuda Lintas Agama sebagai organisasi kepemudaan di samping membantu pelaksanaan tugas dan fungsi FKUB Provinsi Kalimantan Timur, juga memiliki tugas yang penting dalam mengkomunikasikan dan mengsinkronisasikan kepentingan-kepentingan FKUB khususnya dalam mengatasi berbagai macam permasalahan-permasalahan serta konflik sosial yang dihadapi oleh Forum Komunikasi Kerukunan Umat Beragama (Antonius Haryanto, 2019). Hal ini dilakukan melalui dialog lintas agama yang memberikan kesempatan bagi orang dengan berkeyakinan agama yang berbeda untuk saling terlibat dengan satu sama lain agar belajar tentang keyakinan agama masing-masing. Penulis meyakini bahwa hal tersebut dapat menunjukkan sikap masyarakat terhadap keberagaman agama berkorelasi kuat dengan jumlah pengetahuan seorang yang memiliki tentang keyakinan berbeda. Dengan kata lain, semakin seseorang tahu tentang agama tertentu semakin besar kemungkinan seseorang itu akan memiliki pandangan yang positif tentang agama tersebut. Hal ini biasanya dilakukan oleh FKUB dan Pemuda Lintas Agama dengan mengumpulkan berbagai tokoh-tokoh lintas agama untuk berdialog dalam memecahkan permasalahanpermasalahan sosial yang ada.

Dalam rangka melakukan komunuikasi mengenai hal-hal yang berkaitan dengan kerukunan kehidupan umat beragama termasuk gejolak sosial yang sering melanda negeri ini, maka dengan dibentuknya para pemuda dalam forum Pemuda Lintas Agama, diharapkan dapat menjadi wadah berdialog/berbincang hal-hal yang tentu terfokus pada peran baik pemerintah, lembaga keagamaan maupun organisasi masyarakat dan organisasi kepemudaan dalam menjaga kerukunan. Eksistensi keberadaan Pemuda Lintas Agama yang diisi oleh kalangan muda dari perwakilan agama tak bisa dilepaskan dari keberadaan induknya, yakni Forum Kerukunan Umat Beragama (FKUB) yang bersama-sama menggiatkan dan menjaga nilai-nilai kerukunan (Akademika, 2017).

Penulis berkesempatan untuk hadir dalam acara Kemah Pemuda Lintas Agama yang dilaksanakan oleh Kantor Wilayah Kementerian Agama bersama dengan pengurus Forum Kerukunan Umat Beragama dan Pemuda Lintas Agama Provinsi Kalimantan Timur pada hari Rabu hingga Juma't (28-30/2018) yang berlokasi di lapangan terbuka Kelurahan Simpang Pasir, Kecamatan Palaran, Kota Samarinda. Dengan mengambil tema "Membumikan Toleransi dan Kerukunan antar Umar Beragama dalam Bingkai NKRI", dialog ini dapat mewujudkan kesatuan dalam pembauran sehingga mendukung pelaksanaan pembangunan kepemudaan, khususnya pembangunan di sektor keagamaan. Pada dasarnya kegiatan perkemahan Pelita ini digelar dalam rangka peningkatan nilai kerukunan, khususnya di kalangan anak muda. Peserta Kemah Pelita berjumlah 354 orang, terdiri atas perwakilan Provinsi Kalimantan Utara empat orang, perwakilan kabupaten/kota dan Provinsi Kalimantan Timur 60 orang, lembaga keagamaan 62 orang, serta perawakilan madrasah sebanyak 138 orang.

Forum Pemuda Lintas Agama menjadi wadah yang penting bagi generasi muda dalam mewujudkan kerukunan umat beragama melalui suatu dialog lintas agama yang ada. Hal ini dapat terlihat dari hasil wawancara yang penulis lakukan di atas, dimana hampir semua informan dan key informan menyatakan bahwa berbagai masalah-masalah sosial yang berhubungan dengan lintas agama sangat efektif apabila diselesaikan melalui dialog dengan para tokoh-tokoh agama, tokoh adat, dan tokoh masyarakat (Sunan et al., 2010). Dilaksanakannya kegaitan dialog oleh FKUB dengan melibatkan Pemuda Lintas Agama tidak hanya 
111 Peran Pemuda Lintas Agama dalam Meningkatkan Kerukunan Umat Beragama di Provinsi Kalimantan Timur-Deandlles Christover

DOI: https://doi.org/10.31004/edukatif.v4i1.1762

dilakukan ketika adanya masalah sosial yang muncul di tengah kehidupan masyarakat Kalimantan Timur, akan tetapi dialog ini juga dijadikan sebagai sarana menjalin hubungan silahturahmi antar tokoh- tokoh umat beragama yang ada di Kalimantan Timur. Hal ini dapat terlihat dari adanya kegiatan dialog rutinitas yang dilakukan oleh FKUB dengan melibatkan Pemuda Lintas Agama di setiap kegiatan-kegiatan keagamaan atau perayaan- perayaan umat beragama tertentu.

Tabel 1

Kegiatan Dialog Pemuda Lintas Agama

\begin{tabular}{|c|c|c|c|c|c|}
\hline No. & Kegiatan & Tema & Tempat & $\begin{array}{l}\text { Jumlah } \\
\text { Peserta }\end{array}$ & Waktu \\
\hline 1. & $\begin{array}{l}\text { Kemah Pemuda } \\
\text { Lintas Agama }\end{array}$ & $\begin{array}{l}\text { Membumikan Toleransi dan } \\
\text { Kerukunan antar Umat } \\
\text { Beragama dalam Bingkai } \\
\text { NKRI }\end{array}$ & $\begin{array}{l}\text { Lapangan terbuka } \\
\text { Kelurahan Simpang } \\
\text { Pasir, Kecamatan } \\
\text { Palaran, Kota } \\
\text { Samarinda }\end{array}$ & $\begin{array}{c}354 \\
\text { Orang }\end{array}$ & $\begin{array}{c}28-30 \\
\text { November } 2018\end{array}$ \\
\hline 2. & $\begin{array}{l}\text { Perayaan tahun } \\
\text { Baru Imlek } 2570\end{array}$ & $\begin{array}{l}\text { Penimbunan Kekayaan Akan } \\
\text { Menimbulkan Perpecahan di } \\
\text { Antara Rakyat, Tersebarnya } \\
\text { Kekayaan Akan Menyatukan } \\
\text { Rakyat }\end{array}$ & $\begin{array}{l}\text { Gedung Paguyuban } \\
\text { Kim Moy Kota } \\
\text { Samarinda }\end{array}$ & - & $\begin{array}{l}15 \text { Februari } \\
2019\end{array}$ \\
\hline
\end{tabular}

\section{Melakukan Sosialisasi Kerukunan Umat Beragama}

Organisasi Pemuda Lintas Agama sebagai organisasi kemasyarakatan di samping melaksanakan tugas dan fungsinya yang sesuai dengan Keputusan Ketua Forum Kerukunan Umat Beragama Provinsi Kalimantan Timur Nomor 08 Tahun 2016, tidak hanya dapat bekerjasama dengan pihak FKUB. Namun juga dapat berperan dan membantu program-program kerja dengan pihak TNI-Polri, dan organisasi kepemudaan lainnya. Dimana semua komponen tersebut bersama-sama mencegah hal-hal yang dapat memprovokasi kemudian menjurus hal yang bersifat sensitif pada setiap pemeluk agama. Oleh karena itu, Pemuda Lintas Agama sebagai corong masa depan untuk menjaga kerukunan haruslah diberikan pembekalan yang dapat bersinergi dengan tugas dan fungsi dari FKUB. Salah satunya melalui sosialisasi mengenai kerukunan umat beragama, yang bisa dilakukan melalui dialog lintas agama, koordinasi keagamaan dengan berbagai pihak, dan membantu program kerja dari FKUB sendiri. Untuk mewujudkan suatu kondisi kerukunan, maka perlu dilaksanakan interaksi antar para pemeluk agama, baik itu melalui dialog, sosialisasi, tatap muka, ataupun berbagai kegiatan positif yang dapat memupuk rasa persatuan di antara kerukunan umat beragama.

Tujuan dialog serta sosialisasi yang dilaksanakan oleh Pemuda Lintas Agama tidak lain adalah untuk memantapkan kerukunan antar umat beragama, yang dilatarbelakangi multikultural, menciptakan kesamaan visi dan pola pikir serta tindakan dalam organisasi serta menghormati umat beragama. Sejauh ini peran yang dilakukan oleh Pemuda Lintas Agama memang meliputi pada aktivitas dialog dan sosialisasi yang dilakukan dengan sasaran kaum muda pada umumnya. Hal tersebut dikarenakan lebih efektif dan tepat sasaran (Muhdina, 2014).

Hadirnya Pemuda Lintas Agama sebagai organisasi kepemudaan tentulah dapat mendorong jiwa bekerjasama dan saling membantu antar pemuda bagi kepengurusan FKUB guna menjaga keutuhan, kerukunan dan kestabilan antar umat beragama dengan kemampuan yang dimiliki oleh masing-masing pengurusnya melalui sosialisasi yang berkaitan dengan kerukunan umat beragama. Kendati demikian, kerukunan tidak serta merta menjadi tanggung jawab FKUB dan Pemuda Lintas Agama semata namun juga tanggung jawab semua umat beragama untuk menjaga kerukunan di Kalimantan Timur. Oleh karenanya pemahaman akan toleransi tidak hanya diucapkan, tapi juga dibuktikan dengan tindakan dan perbuatan seharihari (Bernhard, 2014). 
112 Peran Pemuda Lintas Agama dalam Meningkatkan Kerukunan Umat Beragama di Provinsi Kalimantan Timur-Deandlles Christover

DOI: https://doi.org/10.31004/edukatif.v4i1.1762

\section{Pembahasan}

Terkait dengan peran Pemuda Lintas Agama yang ada di Kalimantan Timur, dapat dinilai dari beberapa aspek-aspek peran seperti aspek peran sebagai strategi, aspek peran sebagai alat komunikasi, dan peran sebagai alat penyelesaian sengketa.

Dilihat dari aspek peran sebagai sebuah strategi, Pemuda Lintas Agama melakukan kegiatan berupa sosialisasi dan dialog yang dapat dimaknai sebagai sebuah strategi yang bersifat persuasif atau pendekatan yang bersifat soft kepada masyarakat, khususnya komunitas pemuda yang ada di Kalimantan Timur untuk menyampaikan nilai-nilai kerukunan beragama dan sikap saling menghormati antar masyarakat yang berbeda agama. Jika masyarakat sudah memiliki pengetahuan mengenai toleransi, apalagi dalam lingkup pemuda yang masih bisa berpikir kritis dan aktual, maka perpecahan atau konflik yang melibatkan sentimen agama akan lebih mudah untuk dicegah. Hal ini juga berarti masyarakat atau pemuda di Kalimantan Timur akan memiliki sikap saling memiliki satu sama lain dan memiliki akases terhadap pengambilan keputusan, khususnya pada diri sendiri, untuk tidak melakukan perilaku-perilaku yang mengarah kepada kebencian terhadap suatu agama tertentu (Dakwah \& Ilmu, 2017).

Jika dilihat dari peran Pemuda Lintas Agama sebagai alat komunikasi, maka peran Pemuda Lintas Agama ini harus dipersepsikan bahwa Pemuda Lintas Agama adalah alat dari FKUB untuk mendapatkan informasi terkait dengan kegiatan keagamaan maupun informasi terkait dengan bibit-bibit konflik berbau sentimen agama yang ada di masyarakat. Hal ini tidak terlepas dari keanggotaan Pemuda Lintas agama yang tersebar di berbagai daerah yang ada di provinsi Kalimantan Timur. Kegiatan-kegiatan yang dilakukan oleh Pemuda Lintas Agama selain sebagai sebuah sosialisasi, namun juga sebagai wadah untuk mendapatkan informasi langsung dari masyarakat terkait dengan isu-isu agama yang diperlukan oleh FKUB dalam pengambilan keputusan terkait isu-isu agama. Sehingga keputusan yang dihasilkan merupakan keputusan yang responsif dan berbasis dari masukan masyarakat sehingga keputusan yang diambil akan lebih tepat sasaran.

Berlanjut pada aspek peran Pemuda Lintas Agama sebagai alat penyelesaian sengketa dimana dalam hal ini Pemuda Lintas Agama berperan dalam upayanya untuk meredam konflik yang berbasis agama. Adapun cara yang dilakukan adalah melalui pendekatan persuasif yang menyasar langsung pada generasi muda yang dipersepsikan mudah untuk dipengaruhi oleh hal-hal yang menjurus pada konflik. Peran ini memiliki keterkaitan yang erat dengan peran Pemuda Lintas agama sebagai alat komunikasi dimana memang cara yang dilakukan oleh Pemuda Lintas agama adalah dengan banyak melakukan kegiatan-kegiatan yang berbasis dialog antar agama dengan tujuan para pemuda ataupun masyarakat yang menjadi tujuan sasaran kegiatan mereka mengetahui bahwa dalam berkehidupan bermasyarakat di Kalimantan Timur itu tidak hanya berdasarkan pemahaman satu agama saja namun juga terdapat pemahaman agama yang lain yang tentunya memiliki perbedaan- perbedaan dalam menjalankannya. Dengan mengadakan kegiatan dialog antar pemuda maupun masyarakat yang berbeda agama, maka konsensus yang ingin dicapai, yaitu terciptanya situasi kehidupan masyarakat yang damai dan harmonis akan lebih mudah tercapai sebagaimana fakta-fakta yang disampaikan oleh para stake holder di hasil penelitian yang dilakukan oleh penulis, baik itu dari Pemuda Lintas Agama, FKUB, maupun dari pemerintah itu sendiri.

Cara-cara dialog dan pendekatan yang bersifat persuasif ini lebih tepat memang dilakukan dalam lingkup masyarakat Kalimantan Timur yang bersifat multikultural. Hal ini disebabkan karena potensi gesekan ataupun konflik cukup terbuka mengingat di lingkup Kalimantan Timur, terutama daerah perkotaan, memiliki masyarakat dengan pemeluk agama yang berbeda-beda. Dengan dialog ataupun kegiatan lain yang dibawakan oleh Pmeuda Lintas Agama yang membawa misi toleransi, perdamaian, sikap tenggang rasa, pengertian, penerimaan terhadap perbedaan yang dilakukan ini merupakan cara meredam konflik yang sangat baik. Hal ini terlihat jelas dari sangat minimnya konflik yang terjadi di Kalimantan Timur yang didasari perbedaan paham keagamaan maupun tekanan dari mayoritas suatu agama tertentu kepada minoritas agama tertentu. Jika kita berkaca pada fakta bahwa minim sekali konflik yang terjadi di Kalimantan Timur, bahkan untuk rentang 5 
113 Peran Pemuda Lintas Agama dalam Meningkatkan Kerukunan Umat Beragama di Provinsi Kalimantan Timur-Deandlles Christover

DOI: https://doi.org/10.31004/edukatif.v4i1.1762

tahun ke belakang, maka tidak menjadi sebuah pertanyaan yang sulit untuk dijawab mengapa Kalimantan Timur bisa mendapatkan penghargaan sebagai salah satu provinsi dengan tingkat kerukunan masyarakatnya yang tinggi di Indonesia.

Kondisi wilayah yang stabil dan aman dari situasi yang bersifat konfliktual merupakan salah satu sumber daya yang tak terlihat (intangible factor) yang tidak bisa diukur dengan angka-angka kuantitatif. Dengan keterlibatan pemuda di dalamnya, maka pemuda sebagai sumber daya sekaligus agen perubahan sosial akan mampu menciptakan ketahanan nasional di daerah dan menjadi salah satu faktor kesuksesan daerah dalam menciptakan situasi kondusif yang berujung pada ketahanan nasional di daerah.

Oleh karenanya, peran aktif Pemuda Lintas Agama haruslah diberi dukungan yang lebih, baik dukungan dana maupun dukungan moril, agar peran aktif pemudanya dapat berjalan dengan lebih maksimal. Meskipun Pemuda Lintas Agama dalam menjalankan perannya menemukan hambatan, seperti terbatasnya anggaran, terbatasnya anggota, serta eksistensi Pemuda Lintas Agama yang belum dikenal di kalangan muda pada umumnya, namun sejauh ini dengan keterbatasan yang ada, penulis mengamati bahwa peran Pemuda Lintas Agama saat ini berjalan dengan baik.

Untuk memahami mengapa masyarakat maupun pemuda yang semula tidak bisa menerima perbedaan tetapi setelah menerima penjelasan melalui dilaog maupaun kegiatan lainnya pada akhirnya bisa bersikap terbuka, hal ini dapat dijelaskan melalui pemahaman akan konsep pemahaman lintas budaya atau cross cultural understanding. Pemahaman lintas budaya mengasumsikan bahwa seseorang tidak akan bisa menerima pemahaman budaya yang berbeda dengan dirinya sebelum dia mendapatkan penjelasan yang utuh melalui komunikasi yang bersifat persuasif terkait dengan budaya yang berbeda dengannya. Kondisi masyarakat Kalimantan Timur yang bersifat plural, bukan hanya terdiri dari berbagai jenis agama namun juga terdiri dari berbgai jenis suku dan bahasa daerah yang berbeda-beda sehingga pemahaman masyarakat terkait dengan perbedaan agama, budaya dan etnis akan sangat mempengaruhi bagaimana situasi lingkungan dimana mereka hidup dan tinggal. Dengan kegiatan-kegiatan yang dilakukan oleh Pemuda Lintas Agama yang membawa misi perdamaian, toleransi beragama, dan nilai-nilai kesatuan berasaskan Bhinneka Tungal Ika, maka sesungguhnya tujuan utama yang juga ingin dicapai oleh Pemuda Lintas Agama adalah masyarakat atau pemuda yang memiliki pemahaman lintas budaya yang baik.

Penulis meyakini, dengan memahami lintas budaya atau Cross Cultural Understanding (CCU), hal merupakan suatu kompetensi yang sangat dibutuhkan oleh manusia di masa kini dan masa yang akan datang. Aktivitas manusia merupakan produk dari budaya, dan produk ini akan saling berinteraksi dalam masyarakat plural tanpa batas. Hal positif dan negatif berinteraksi dengan cara pandang yang baru. Hal ini memungkinkan manusia perlu memahami budaya bahkan agama orang lain, agar dapat berkomunikasi secara efektif dan efisien. Dengan mengenal perbedaan yang ada, aktivitas, kebutuhan serta kebiasaan, maka seseorang dibekali untuk memahami berbagai bentuk perbedaan, berkomunikasi dengan cara yang tepat dan tidak mengalami benturan budaya/gegar budaya (shock culture).

Masyarakat yang memiliki pemahaman lintas budaya yang baik akan dengan mudah menerima perbedaan budaya dari masyarakat di sekitanya. Dengan pemahaman lintas budaya yang baik pula, kondusifitas lingkungan kehidupan bermasyarakat akan dapat dengan lebih mudah tercapai. Kemajemukan yang terdapat di Indonesia rawan dibumbui oleh emosi yang ego masing-masing kelompok serta ditambah dengan kesalahpahaman kecil antar pemuda dapat menyebabkan terjadinya konflik-konflik besar dan sangat disayangkan konflik yang terjadi tersebut seringkali mengatasnamakan perbedaan agama. Hal ini jugalah yang diupayakan oleh Pemuda Lintas Agama, seperti salah satu contohnya yakni mengunjungi tempat-tempat ibadah, guna mengenali masing-masing perbedaan serta menjalin rasa toleransi antar sesama pemeluk agama.

Ketiga, membangun kerjasama antar pemeluk agama, khususnya melalui organisasi-organisasi massa yang ada khususnya pada orgnaisasi-organisasi keagamaan. Berdasarkan analisis peneliti, sikap kepedulian yang dimiliki oleh anggota Pemuda Lintas Agama sudah sangat solid dan kompak. Meskipun dalam beberapa 
114 Peran Pemuda Lintas Agama dalam Meningkatkan Kerukunan Umat Beragama di Provinsi Kalimantan Timur-Deandlles Christover

DOI: https://doi.org/10.31004/edukatif.v4i1.1762

acara ada beberapa anggota yang tidak dapat hadir atau mengikuti kegiatan yang berlangsung, namun hal tersebut tidak menyurutkan semangat anggota yang lain. Hal ini terbukti dengan yang disampaikan Arif, bahwa Pelita juga langsung berkomunikasi dengan anggota-anggota Pemuda Agama di luar Pelita seperti Pemuda Katolik, Pemuda Anshor, Pemuda Muhammadiyah, dan lainya untuk ikut serta dalam kegiatan dan mereka tetap dianggap sebagai bagian dari Pemuda Lintas Agama. Selain itu, peranan Pemuda Lintas Agama yang juga selalu hadir dalam membantu Forum Kerukunan Umat Beragama menjadi sangat penting mengingat generasi mudalah yang mampu menggerakkan serta mempengaruhi kaum muda untuk membangun sikap saling kerjasama di antara pemeluk agama.

Keempat, membangun dialog antar umat beragama, ini sudah dilakukan oleh Pemuda Lintas Agama dan hal tersebut sudah menjadi kegiatan rutin. Karena dengan dialog dan tatap mukalah, proses komunikasi itu dapat berjalan dengan baik dan tepat sasaran. Hal ini sejalan dengan yang disampaikan oleh Said Agil, bahwa melalui dialog dan tatap muka antar umat beragama merupakan dua proses komunikasi kerjasama antar umat beragama yang tidak dapat dipisahkan. Sebab, salah satu bagian dari kerukunan antar umat beragama adalah perlu dilakukannya dialog antar agama.

\section{KESIMPULAN}

Berdasarkan hasil penelitian dan pembahasan pada bab sebelumnya maka dapat ditarik kesimpulan sebagai berikut:

Pemuda Lintas Agama dalam membangun dialog dengan masyarakat dan pemuda melalusi setiap kegiatannya, selalu menanamkan sikap atau pemahaman mengenai pentingnya masyarakat untuk memahami budaya dari suku, agama dan ras yang berbeda. Dengan pemahaman yang bersifat lintas budaya, masyarakat dan pemuda tidak akan mudah untuk mengalami gegar budaya. Hal ini terbukti dengan minimnya konflik yang disebabkan oleh faktor budaya, etnis, dan agama.

Adapun yang menjadi saran penulis berdasarkan hasil pembahasan dan kesimpulan adalah sebagai berikut:

Karena masalah kebhinekaan dan peningkatan kerukunan umat beragama merupakan isu yang sangat krusial dalam kehidupan berbangsa dan bernegara, maka peran organisasi Pemuda Lintas Agama dalam membantu FKUB perlu lebih ditingkatkan. Oleh karenanya, Pemerintah Provinsi Kalimantan Timur dan kabupaten/kota perlu segera menganggarkan anggaran bagi organisasi-organisasi kepemudaan yang peduli terhadap kerukunan dan toleransi umat beragama. Karena keterbatasan anggaran yang diperoleh oleh organisasi Pemuda Lintas Agama yang merupakan mitra kerja dari FKUB, maka Pemerintah Daerah Provinsi Kalimantan Timur wajib mengalokasikan anggaran APBD untuk organisasi tersebut.

Agar organisasi Pemuda Lintas Agama bisa berjalan lebih baik, maka pemerintah melalui FKUB perlu melakukan pembinaan dan pelatihan terhadap anggota-anggota Pemuda Lintas Agama tentang pentingnya menjadi pemuda pelopor kerukunan umat beragama.

Organisasi Pemuda Lintas Agama yang relatif baru sesuai dengan Surat Keputusan Forum Kerukunan Umat Beragama (FKUB) Provinsi Kalimantan Timur Nomor 08 tahun 2016, maka FKUB Provinsi Kalimantan Timur perlu mensosialisasikan Pemuda Lintas Agama ini kepada stakeholder-stakeholder terkait.

\section{DAFTAR PUSTAKA}

Ahmad, A. K. (2010). Potensi Kerjasama Pemuda Lintas Agama di Sorong. Jurnal “Al-Qalam,” 16.

Akademika, W. (2017). Peran Forum Pemuda Kerukunan Umat. 4(April).

Antonius Haryanto, R. (2019). Badan Sosial Lintas Agama (BASOLIA). Religió: Jurnal Studi Agama-Agama, 9(1), 111-133. https://doi.org/10.15642/religio.v9i1.1237

Anonim. 2009. Undang-Undang Nomor 40 Tahun 2009 tentang Kepemudaan 
115 Peran Pemuda Lintas Agama dalam Meningkatkan Kerukunan Umat Beragama di Provinsi Kalimantan Timur-Deandlles Christover

DOI: https://doi.org/10.31004/edukatif.v4i1.1762

Bernhard, T. (2014). Kaum Muda dan Dialog Lintas Agama Bagaimana Kaum Muda dapat Memberi Kontribusi untuk pembangunan toleransi agama di Indonesia? December.

Bennet, J. M., Bennet, M. J., \& Allen, W. 2003. Developing Intercultural Competence

Brett, J. M. 2000. "Culture and Negotiation”, International Journal of Psychology Vol. 32 No. 2.

Corbett, J. 2003. An Intercultural Approach To Second Language Education. In The Language Classroom. In lange, D. L., \& Paige, M. (Eds.). Culture As The Core: Perspectives On Culture In Second Language Learning (pp. 237- 270). Greenwich: Information Age Publishing.

Dakwah, F., \& Ilmu, D. A. N. (2017). Fakultas dakwah dan ilmu komunikasi universitas islam negeri (uin) raden intan lampung $1438 \mathrm{~h} / 2017 \mathrm{~m}$.

Dewantara, Agustinus. 2019. Diktat Kuliah: Ilmu Perbandingan Agama. Madiun

Dewantara, A. (2018). Alangkah Hebatnya Negara Gotong Royong (indonesia Dalam Kacamata Soekarno).

Elizabeth K. Nottinghan, (1994). Agama dan Masyarakat, Jakarta: PT Raja Grafindo Persada.

Hermawati, Rina, (2016). "Toleransi Antar Umat Beragama” dalam jurnal Umbara Vol. 1 (2).

Huda Thoriq. (2018). Potret Kerukunan Pemuda Lintas Agama di JATIM. UIN Sunan Ampel, April, 929-936.

Ichwayudi, B., \& Yardho, M. Menangkal potensi radikalisme pada pemuda melalui dialog lintas agama: analisis terhadap program forum kerukunan umat beragama bagi pemuda lintas agama di Jawa Timur (Doctoral dissertation).

Kurniawan, A. (2019). Kemesraan Lintas Agama Para Suster Katolik Dan Grup Musik Kasidah Islami Dalam Pandangan Sosiologi Agama Serta Relevansinya Dalam Kehidupan Sehari-hari.

Muhdina, D. (2014). Program pascasarjana univeristas islam negeri alauddin makassar 2014. Disetrtasi, 3.

Pangalila, T. (2018). Jurnal Civic Education, Vol. 2 No. 1 Juni 2018. Theodorus Pangalila, 2(1), 15-24. https://ppjp.ulm.ac.id/journal/index.php/pkn/article/viewFile/3553/3082

Pradnyaningrat, G. A. . A. D., Sudiana, I. G. N., \& Laksana Utama, P. K. (2020). Strategi Komunikasi Forum Kerukunan Umat Beragama dalam Pembinaan Kerukunan Umat Lintas Agama di Kabupaten Mojokerto. Widya Duta: Jurnal Ilmiah Ilmu Agama Dan Ilmu Sosial Budaya, 14(2), 16. https://doi.org/10.25078/wd.v14i2.1223

Prawira, Rangga, (2010). "Hubungan Antara Makna Hidup Dengan Toleransi Beragama Pada Jamaah Salafy di Bekasi”, Jakarta: UIN Syarif Hidatullah.

RAYA, K. P. Peran Pemuda dalam Menjaga Kerukunan Antar Umat Beragama Berlandaskan Huma Betang di Desa Tumbang Kalang.

Sarwono, Sarlito W, Meinarno, Eko A. 2009. Psikologi Sosial. Salemba Humanika: Jakarta.

Schuon, Frithjof. 1987. Mencari Titik Temu Agama-Agama. Yayasan Obor Indonesia: Jakarta.

Simamora, E. (2019). Konsepsi Peningkatan Peranan Kerukunan Umat Beragama Guna Menciptakan Solidaritas Nasional dalam Rangka Ketahanan Nasional. KERUGMA: Jurnal Teologi Dan Pendidikan Agama ..., 1(1), 1-16. http://www.sttiimedan.ac.id/e-journal/index.php/kerugma/article/view/1

Soekanto, Soejono. 1992. Sosiologi: Suatu Pengantar. Rajawali Press: Jakarta.

. 2009. Teori Peranan. Bumi Aksara.

Sunan, I., Surabaya, A., \& Djalal, A. (2010). Fakultas Ushuluddin. 0291, 1-14.

Wibowo, T. (2016). Peran Tokoh Agama dalam Menjaga Kerukunan Antar Umat Beragama Di Desa Sekaran Kecamatan Kayen Kidul Kabupaten Kediri. Kajian Moral dan Kewarganegaraan, 2(4). 